\title{
STATUS SŁOWOTWÓRCZYCH ELEMENTÓW KLASYCZNYCH W WYBRANYCH UJĘCIACH JĘZYKOZNAWCÓW SLOWIAŃSKICH
}

\section{Status of Classical Word-formative Elements in Selected Approaches of Slavic Linguists}

Keywords: Bulgarian, Slovak, Polish, prefix, sufix, afixoids, compounds, wordformative element

Contact: Uniwersytet Śląskiw Katowicach; a.wojnarowska93@gmail.com

\section{Wstęp}

Określenie roli obcych komponentów w procesie internacjonalizacji leksyki, a przede wszystkim ich statusu słowotwórczego, stanowią przedmiot badań lingwistów od drugiej połowy XX wieku. Jednocześnie przedstawione badania prezentują różnorodne podejścia względem elementów obcych i wskazują na brak jednomyślności w kwestii ich typologii. Celem tego artykułu jest więc naświetlenie i próba porównania poglądów wybranych językoznawców słowackich, polskich i bułgarskich dotyczących statusu formalno-gramatycznego cząstek obcych (głównie klasycznych) ${ }^{1}$.

Motywacją do przeprowadzenia niniejszej komparacji jest chęć określenia statusu słowotwórczego elementów występujących w terminologii okulistycznej w językach bułgarskim i słowackim. Mowa o cząstkach występujących w terminach klasyfikowanych jako internacjonalne, w których, element obcy (klasyczny) łączy się z obcą podstawą słowotwórczą. Choć opracowania lingwistyczne nie podejmują raczej próby klasyfikacji obcych cząstek w ramach profesjolektu medycznego, rozbieżności pojawiające się $\mathrm{w}$ interpretacji takich cząstek, nawet na gruncie poszczególnych języków narodowych zasługują na uwagę. Cząstki wyekscerpowane podczas badań mają pochodzenia greckie i łacińskie, są to m.in.: $a(H)$ - / $a(n)-$; bio- / бuo-; extra- /

\footnotetext{
${ }^{1}$ Temat statusu słowotwórczego cząstek obcych jest bardzo szeroki. Niniejszy artykuł stanowi ogólny przegląd klasyfikacji takich cząstek w językach, które są analizowane w powstającej rozprawie doktorskiej na temat terminologii okulistycznej w języku słowackim i bułgarskim.
} 
екстра-; суб- / sub-; foto- / фото-; хетеро- / hetero-; хипер- / hiper-; xuno- / hypo-; интер- / inter-; микро- / mikro-; моно- / топо-; nара- / para-; теле- / tele-, itp.

Te i podobne im elementy są zaliczane przez różnych językoznawców do derywacji lub kompozycji. Cząstki o charakterze prepozycjonalnym określane są jako prefiksy, prefiksoidy, poloprefiksy, polomorfemy, prepozitivni afixoidy (por. Waszkowa 2005; Kaproń-Charzyńska 2004; Селимски 2003; Furdík 2004). Inni lingwiści elementy obce (także wygłosowe) uznają za człony złożeń, interpretując struktury z ich udziałem jako złożenia bezinterfiksalne / bezafiksalne, złożenia z członem (nie)samodzielnym, złożenia z członem powtarzalnym czy quasi-złożenia. W badaniach lingwistów bułgarskich, czeskich i słowackich pojawiają się dodatkowo takie określenie obcych cząstek jak: radixoid, лексико-морфема, bázoid, czy też dość ogólnie ujęty internacionálny komponent.

\section{Prefiksy $^{2}$}

Różnice w rozumieniu poszczególnych elementów obcych można zauważyć nie tylko podczas komparacji interlingwalnej, ale również w obrębie jednego języka. Pojęcie prefiks (pl. przedrostek, sk. predpona, bg. представка) ${ }^{3}$ to pojęcie raczej ustabilizowane w polskiej, słowackiej czy bułgarskiej lingwistyce. Charakteryzowane są jako formant słowotwórczy występujący przed rdzeniem (Grzegorczykowa, Puzynina 1999a: 366; Furdík 2004: 93).

K. Waszakowa w swojej monografii (Waszakowa 2005) wydziela nieliczną grupę elementów obcych, którym nadaje status prefiksu; zalicza do nich m. in. $a$-, anty-, de- // dez-, dys-, ekstra-, hiper-, kontr-, sub-, super-. Ta klasyfikacja jest podyktowana włączeniem w zakres prefiksacji takich konstrukcji, których znaczenie (komunikowane przez powtarzalny element obcy, nie mający statusu samodzielnego wyrazu) może być $\mathrm{w}$ pełni oddane lub przybliżone przez odpowiedni rodzimy przyrostek bądź przyimek (Waszakowa 2005: 54-55). Podobne podejście prezentują R. Grzegorczykowa i J. Puzynina przyjmując, że podstawą w typologii cząstek słowotwórczych może być ich rodzimość lub obcość (Grzegorczykowa, Puzynina 1999b: 465-468).

Dosyć szeroki zakres prefiksacji na płaszczyźnie języka bułgarskiego w odniesieniu do obcych morfemów przyjmuje L. Selimski. Jako prefiksy traktuje m.in.,

\footnotetext{
${ }^{2}$ Ze względu na przedmiot badań (cząstki nagłosowe) i szeroki zakres tematyczny z nimi związany w artykule nie wspomina się szczegółowo o sufiksach, a jedynie o cząstkach o przechodnim charakterze, które odnoszą się do kompozycji lub derywacji jak np. formantoidy, afiksoidy (w tym sufikso- i radiksoidy).

${ }^{3}$ Podobnie pojęcie sufiks (pol. przyrostek, sk. prípona, bg. наставка) czy ogólne afiks (formant) również są definiowane $\mathrm{w}$ analizowanych językach jednorodnie.
} 
struktury typu: $а($ н)-, де- (дез-), дис-, интер-, пара-, супер-, транс-, ултра-, хипер-. Podobne stanowisko na gruncie języka polskiego przyjmuje J. Bartmiński dodając do powyższego zbioru także inne cząstki pochodzenia klasycznego, np. tele-, wideo-, bio-, mini-, maksi (por. Bartmiński 2000: 111).

C. Avramowa (Avramowa 2002: 24) w studium porównawczym bułgarskoczeskim jako prefiksy klasyfikuje paralelne cząstki armu- / anti, de- / de-, nocm- / post-, хипер- / hyper, псевдо- / pseudo-, cynep- / super-, itp. Wymienione przedrostki badaczka uważa za niepodzielną część systemu słowotwórczego języka bułgarskiego i czeskiego, które standardowo łączą się z podstawami rodzimymi.

\section{Prefiksoidy}

O wiele mniejszą zgodność obserwuje się wśród badaczy w kwestii typologii tego, co jest prefiksoidem lub członem złożenia oraz czym te dwie formacje różnią się od prefiksu. Określeniu czym ma być prefiksoid miało służyć na gruncie języka polskiego wprowadzenie przez polskie lingwistki - R. Grzegorczykową i J. Puzyninę, bardziej ogólnego pojęcia formantoid dla wyrazów, które są: podzielne jednostronnie -

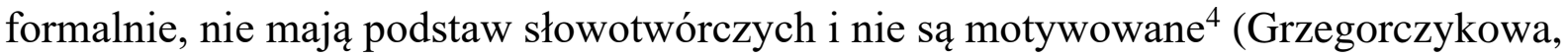
Puzynina 1979: 24).

Inaczej afiksoidy (prefiksoidy / sufiksoidy) są opisywane w słowackiej i czeskiej lingwistyce. J. Furdík definiuje afixoidy jako człony złożeń, które zostały zdegradowane do poziomu środka derywacyjnego: ,(..) útvary, ktoré spočiatku fungovali ako slovotvorné základy zložených slov, ale pri častejšiom tvorení príslušných kompozít ich vlastná sémantika zoslabla, takže poklesli na úroveň derivačného prostriedku afixoidu" (Furdík 2004: 46-47). Za prefiksoidy J. Fudík uznaje struktury typu: eko-, mini-, maxi-, makro-, tele-, itp. (Furdík 2004: 46-47).

Bardzo podobnie afiksoid jest rozumiany przez C. Avramovą, czerpiąca głównie z założeń Olgi Martincovej i Nikolaja Savickiego. Badaczka rozumie aфиксоидu jako „компоненти заемащи мединно положение по отношение на корените и афиксалните морфем” (Аврамова 2003: 33-34; Martincová, Savický 1987: 125). C. Avramova zaznacza, że afikosoidy nie tworzą grupy homogennej, wskazując w swoich badaniach niejednokrotnie na ich nieustabilizowany i niezdefiniowany w pełni dotąd charakter. Do grupy afiksoidów, oprócz prefiksoidów i sufiksoidów,

\footnotetext{
${ }^{4}$ Mowa o cząstkach -ent i -ant w wyrazach, np. docent i adiutant. Te same cząstki będą jednak sufiksami, jeśli wyraz, w którym występują są motywowane - podzielne słowotwórczo, a ich znaczenie można opisać za pomocą parafrazy słowotwórczej, np. student, konsultant ('ten, kto studiuje' lub 'ten kto konsultuje') (Grzegorczykowa, Puzynina 1979: 24-25).
} 
zalicza również tzw. radiksoidy (czes. radixoidy) czyli cząstki, których status słowotwórczy można umiejscowić pomiędzy afiksem i rdzeniem (radixem), por. еко-, електро-, енерго-, евро-, крими-, моно-, нарко-, профи (2003: 35-42).

Bułgarscy lingwiści w odniesieniu do określenia radiksoid (bułg. paдиксоид) używają również zaczerpniętego z lingwistyki rosyjskiej terminu лексико-морфема, definiowanego jako „своеобразен слой лексико-морфологични елементи, загубили морфологичните връзки със своите източници и служещи за образуване на селии серии сложносъкратени думи, които в действителност нямат зад себс си реално съкращаващи съчетани” (Аврамова 2003: 43).

$\mathrm{Na}$ niestabilność koncepcji i trudność w typologizacji opisywanych cząstek wskazuje także fakt, że sami badacze zmieniają swoje podejścia i kryteria klasyfikacji w trakcie analiz. K. Waszakowa, w odróżnieniu od swojej późniejszej klasyfikacji, w studium komparatystycznym polsko-słowacko-czeskim, człony typu: super-, mega-, hiper / hyper-, mini-, mikro-, maksi- / maxi-, pseudo-, multi-, opisuje jako prefiksoidy, zaznaczając, że część językoznawców traktuje je jako prefiksy oraz, że jako cząstki obce mają zdolność łączyć się z formacjami imiennymi, zarówno obcymi jak i rodzimymi (Waszakowa 2003: 85-100).

\section{Kompozycje}

Struktury obce, poszerzające inwentarz słowotwórczy języków-biorców, nie są badane jedynie przez pryzmat derywacji, ale i kompozycji. Niejednomyślność lingwistów w kwestii członów obcych przejawia się w tym, jak klasyfikują daną jednostkę według ogólnych kryteriów - czy jako samodzielną słowotwórczo albo motywowaną na gruncie właściwego im języka rodzimego. Pluralizm przejawia się także w odniesieniu do kwestii formalnych.

Można przyjąć, że elementy obcego pochodzenia wchodzą w skład złożeń jak czyni to J. Mleczko, zaliczając do internacjonalnych pierwszych członów złożeń segmenty takie jak np: био-, хроно-, хромо-, фото-, гига-, хетеро-, хомо-, хинтер-, мега-, микро-, моно-, теле- ${ }^{6}$ (por. Mleczko 2012: 79). Podobne cząstki są traktowane przez grupę słowackich badaczy jako części złożeń internacjonalnych czy quasi-

\footnotetext{
${ }^{5}$ Jako podstawowe kryterium rozgraniczenia prefiksoidów od radiksoidów autorka przyjmuje opozycję znaczeń przedmiotowe $\neq$ nie przedmiotowe (bg. предметно $\neq$ непредметно) i konkretne $\neq$ abstrakcyjne (bg. конкретно $\neq$ абстрактно). Radiksoidy wyrażają znaczenie przedmiotowe, $\mathrm{z}$ kolei prefiksoidy nie mają znaczenia przedmiotowego i wyrażają stosunki ogólne (lokalne, temporalne, wartościujące, ilościowe, stosunku przeciwwagi, hierarchię) (Радева 2003: 35-42).

${ }^{6}$ Należy jednak zaznaczyć, że w tym samym zbiorze ukazał się sąsiedni artykuł tej samej autorki, w którym opisuje niejednomyślność poglądów, badaczy czeskich i bułgarskim w kwestii opisanych przez nią struktur (por. Mleczko 2012a).
} 
composit (kvázikompozitá, intarnacionálne kompozitá, internacionálne zloženiny) (Horecký, Buzássyová, Bosák et al. 1989: 251-252).

Oprócz kryteriów semantyczno-morfologicznych brany jest pod uwagę także stopień motywacji słowotwórczej. To podejście wydaje się być wyjściowym na gruncie polskiej i słowackiej lingwistyki (por. Waszakowa 2005 oraz Ološtiak, Vojteková, Oriňáková 2019). Można więc wydzielić trzy rodzaje struktur (jednostek):

- struktury o pełnej motywacji (podstawy słowotwórcze, z których składa się złożenie są samodzielne słowotwórczo);

- struktury o niepełnej motywacji (złożenia z jednym członem związanym niesamodzielnym);

- quasi-złożenia (złożenia o dwóch członach niesamodzielnych - związanych).

K. Waszakowa dodatkowo złożenia z członami samodzielnymi dzieli na złożenia z członami o pełnej postaci oraz na złożenia $\mathrm{z}$ członem o postaci skróconej (zdezintegrowanej). Natomiast złożenia z członem niesamodzielnym grupuje razem z quasi-złożeniami, do których zalicza znaczną większość elementów klasycznych. Niektóre człony, których etymologia jest klasyczna, ale ich obecność w systemie słowotwórczym języka polskiego pozwala na określenie ich motywacji, autorka włącza do grupy złożeń zdezintegrowanych, np. auto- od automatyczny; bio- od biologia, biologiczny (por. Waszakowa 2005: 77-80).

O skróconych wyrazach złożonych (съкратени сложни думи) bułgarscy lingwiści piszą również jako o tzw. групови абревиатури (por. Крумова, Чоролеева 1982: 24). Opisują ten typ złożeń jako oscylujące na pograniczu między nimi a wspominanymi wyżej strukturami określanymi jako лексико-морфеми (albo радиксоиди). Według V. Radevej cząstkę, która traci swój związek z podstawą, do której była przyłączona i zbliża się pod względem funkcji do środka słowotwórczego, można traktować jako wspominane лексико-морфеми (Радева 1991: 50).

W Gramatyce współczesnego języka polskiego (Grzegorczykowa, Puzynina 1999b: 466-467) człony obce klasyfikuje się głównie jako segmenty niesamodzielne, powtarzane $\mathrm{w}$ złożeniach jednostronnie motywowanych, a jako najbardziej produktywne wyróżnia się m. in: mono-, poli-, makro-, mikro-, izo-, bio-, endo-, hetero-, tele-. Badaczki określają strukturę złożeń jednostronnie motywowanych i quasi-złożeń jako niejasną i rezygnują z ich interpretacji semantyczno-składniowej (Grzegorczykowa, Puzynina 1999b: 465).

Opisana niejednomyślność w systematyzacji i niemożność wyznaczenia ostrych granic pomiędzy procesami derywacji i kompozycji, w których uczestniczą klasyczne cząstki obce była bodźcem do stworzenia nowego pojęcia na gruncie słowackiej 
lingwistyki. M. Ološtiak. M. Vojteková, S. Oriňáková (2019: 22) proponują termin nowy dla słowackiego językoznawstwa - bázoidy, o których piszą w następujący sposób „komponenty neslovného charakteru (a so zrejmým lexikálnym významom) v kompozitných lexémach budeme nazývat' bázoidy a jednotky $\mathrm{s}$ takýmito komponentmi bázoidné kompozitné lexémy, resp. semikompozitá”. Za podstawowe kryterium delimitacyjne autorzy założyli semantykę. Pełne znaczenie leksykalne przypisują bazie (podstawie słowotwórczej), formanty są natomiast nosicielami znaczenia „semikategorialnego“(Ološtiak, Vojteková, Oriňáková 2019: 17-18)

\section{Podsumowanie}

Jak pokazują powyższe rozważania, dysponując wyekscerpowanymi cząstkami obcymi nie sposób ich jednoznacznie zaklasyfikować w sposób, w jaki pozwalałaby na to logiczna oraz merytoryczna argumentacja. I. Kaproń Charzyńska podejmuje próbę kompleksowej klasyfikacji, biorąc pod uwagę poszczególne wytyczne, proponowane przez innych językoznawców, również rosyjskich i czeskich. Lingwistka uwzględnia formalne i semantyczne relacje słowotwórcze (między derywatami i ich podstawami słowotwórczymi) oraz cechy formalne (miejsce danej cząstki w derywacie - sposób połączenia z innymi członami złożenia, powtarzalność). Wnioski płynące z jej analizy, będące zarazem swoistą klasyfikacją cząstek obcych (nagłosowych i wygłosowych) dzielą elementy obce na afiksy oraz cząstki obce, których afiksami nazwać nie można. $\mathrm{Za}$ afiksy uznane są te elementy, które mogą być wyrażane za pomocą rodzimych również afiksów lub przyimków. Grupa „nie-afiksów” podzielona została na afiksoidy i człony złożeń. Afiksoidy to według autorki te elementy, które w parafrazie słowotwórczej są zastępowane leksemem, który ma związek formalny. Człony złożeń to mianowicie te, które nie są zastępowane leksemem. Klasyfikacja wydaje się być zasadna i pomocna w badaniach, nie ma w niej jednak miejsca na quasi-złożenia czy cząstki typu radiksoidalnego lub bazoidalnego.

$\mathrm{Z}$ opisanych, proponowanych przez różnych językoznawców, klasyfikacji wynikałoby bowiem, że prefiksy, prefikso- (ale i afiksoidy) oraz (pierwsze) człony złożeń wykazują cechy, które przenikają się wzajemnie, ale i wykluczają. Określenie statusu słowotwórczego klasycznych elementów obcych, a następnie ich komparacja w innych językach, okazuje się przy wielości wyznaczanych warunków opisu a jednocześnie niekonsekwencji $\mathrm{w}$ ich stosowaniu trudna. Ilość słowiańskich źródeł literatury przedmiotowej, która powstaje, wydaje się niezasadna, uwzględniając fakt, że

\footnotetext{
${ }^{7}$ Dla porównania: w myśl tej tezy bazoidem będzie cząstka inter- w znaczeniu „internacionálny, medzinárodný“, ale inter- występujący w charakterze przyimka „medzi“ przyjmie status afiksu (Ološtiak, Vojteková, Oriňáková 2019: 28).
} 
nie w pełni rozlicza się ona z powstałymi już próbami typologizacji internacjonalnych słowotwórczych elementów obcych.

W przypadku terminologii okulistycznej pomocna może być szeroko rozumiana medyczna literatura, która klasyfikuje cząstki obce - dość zgodnie - jako prefiksy. Taki podział wydaje się być najwygodniejszy i najbardziej uniwersalny - pozwala na określenie statusu obcych cząstek w terminologii, która również jest zinternacjonalizowana i obca na gruncie wielu innych języków.

\section{Summary}

The following paper is an attempt to present diverse linguistic views on international formative elements of classical (i.e. Latin and Greek) origin, excerpted from reaserch of Bulgarian and Slovak ophthalmological terminology. The paper is divided in three main parts, depicting various concepts about affixes, affixoids and compounds. In the end, a summary provides juxtaposition of the most important information about the described structures and aims to adopt one, most universal classification for typology of foreign word formative elements, occurring in medical terminology.

\section{Literatura}

Avramova, C. Slovotvorné tendence u substantiv v bulharštině a češtině v 80. a 90. letech 20. století. Slavia (68/1), s. 23-33.

Bartmiński, J. Pasywne i aktywne paneuropeizmy we współczesnym języku polskim, In: Mazur, J. (ed.) Słownictwo współczesnej polszczyzny w okresie przemian. Lublin: Wydawnictwo Uniwersytetu Marii Curie-Skłodowskiej, 2000, s. 109116.

Ekes, K. Niezbędnik Kleopatry. Greckie i łacińskie korzenie terminologii nie tylko dla kosmetologów. Warszawa: Wydawnictwo Naukowe Sub Lupa, 2016.

Grzegorczykowa, R., Puzynina, J. Słowotwórstwo współczesnego języka polskiego. Rzeczowniki sufiksalne rodzime. Warszawa: Państwowe Wydawnictwo Naukowe, 1979.

Grzegorczykowa, R., Puzynina, J. Problemy ogólne słowotwórstwa. In: Grzegorczykowa. R., Laskowski, R., Wróbel, H. (eds.) Gramatyka współczesnego języka polskiego. Morfologia. Warszawa: Wydawnictwo Naukowe PWN, 1999a, s. 361-389. 
Grzegorczykowa, R., Puzynina, J. Rzeczownik In: Grzegorczykowa. R., Laskowski, R., Wróbel, H. (eds.) Gramatyka współczesnego języka polskiego. Morfologia. Warszawa: Wydawnictwo Naukowe PWN, 1999b, s. 389-469.

Horecký, J. O slovách s predponou gama-. Kultúra slova. 1981 (15/4), s. 97-99.

Horecký, J., Buzássyová, K., Bosák, J. et al. Dynamika slovenej zásoby súčasnej slovenčiny. Bratislava: Veda, 1989.

Kaproń-Charzyńska, I. 2004. Prefiksy, sufiksy, prefiksoidy, sufiksoidy czy człony związane? Język Polski. 2004 (84/1), s. 16-28.

Mleczko, J. Internacjonalizmy we współczesnym języku polskim i bułgarskim (złożenia). Zeszyty Cyrylo-Metodiańskie. 2012 (1), s. 64-81.

Mleczko, J. Status elementów składniowych niektórych internacjonalizmów w języku polskim i bułgarskim. Zeszyty Cyrylo-Metodiańskie. 2012a (1), s. 82-91.

Landesberg, J. Język łaciński dla studentów weterynarii. Warszawa: Państwowe Wydawnictwo Naukowe, 1975.

Waszakowa, K. Przejawy internacjonalizacji w słowotwórstwie wspótczesnej polszczyzny. Warszawa: WUW, 2005.

Waszakowa, K. Przejawy tendencji do internacjonalizacji w systemach słowotwórczych języków zachodniosłowiańskich. In: Ohnheiser, I. (ed.) Komparacja systemów i funkcjonowania współczesnych języków słowiańskich. 1. Stowotwórstwo / Nominacja. Opole: Uniwersytet Opolski - Instytut Filologii Polskiej i Opolskie Towarzystwo Przyjaciół Nauk. 2003, s. 60-78.

Аврамова, Ц. Словообразувателни тенденциии при съществителните имена в българския и чешкия език в края на XX век. Sofia: Hron Press, 2003.

Крумова, Л., Чоролеева, М. Съкращуаването и съкращения в български език, Sofia: БАН, 1982.

Радева, В. Словообразуването в българския книжовен език. София: Университетско издателство „Св. Климент Охридски“, 1991.

Селимски, Л. Прояви на тенденцията към интернацийонализация в южнославянските езищи,. In: Ohnheiser, I. (ed.) Komparacja systemów ifunkcjonowania współczesnych języków słowiańskich. 1. Słowotwórstwo / Nominacja. Opole: Uniwersytet Opolski - Instytut Filologii Polskiej i Opolskie Towarzystwo Przyjaciół Nauk, 2003, s. 103-127. 


\section{Źródła elektroniczne}

Martincová, O., Savický, N. Hybridní slova a některé obecné otázky neologie. Slovo a slovesnost. Dostęp z: http://sas.ujc.cas.cz/archiv.php?art=3164 (2021-02-21).

Ološtiak, M., Vojteková, M., Oriňáková, S. Slovotvorná adaptácia a kompozitnost' v slovenčine. Dostęp z: http://www.pulib.sk/web/kniznica/elpub/dokument/ Olostiak16 (2021-01-15). 